\title{
Notes on the brain and encephalization quotient of two sperm whales With a synthesis of the literature and indications of a new method of extraction
}

\author{
Michele Povinelli ${ }^{1}$, Mattia Panin ${ }^{1}$, Sandro Mazzariol ${ }^{1}$, Maristella Giurisato ${ }^{1}$, \\ Cristina Ballarin ${ }^{1}$, Giulia Roncon ${ }^{2}$, Michela Podestà ${ }^{3 *}$, Massimo Demma ${ }^{4}$, \\ Bruno Cozzi ${ }^{1}$
}

\begin{abstract}
The sperm whale (Physeter macrocephalus, Linnaeus 1758) possesses the largest brain that ever existed. Relatively few authors have dealt with it and the available descriptions are heterogeneous, with only few data about brain weight or gross anatomy. In fact the central nervous system of large cetaceans is quite difficult to obtain, given the huge body size and the low frequency of strandings of recently dead individuals. Furthermore, since the skull of the sperm whale underwent an extreme transformation for the accommodation of the spermaceti organ, the cranial cavity is surrounded by thick layers of bone and thus difficult to reach under field conditions.

We recently had the chance to extract the brain from two stranded sperm whales whose bodies were in good condition. In the present note we describe the main macroscopic characteristics of the sperm whale brain, including its weight and Encephalization Quotient, review the available literature, and describe a possible new approach to the removal and preservation of the organ under field conditions.
\end{abstract}

Key-words: Sperm whale brain; Encephalization Quotient; marine mammals; strandings; brain weight.

Riassunto - Il capodoglio (Physeter macrocephalus, Linnaeus 1758 ) possiede il cervello più grande mai esistito. Pochi autori hanno trattato questo argomento e le descrizioni pubblicate sono molto eterogenee, con solo pochi dati sul peso e l'anatomia macroscopica. Il sistema nervoso centrale dei grandi cetacei è molto difficile da ottenere, viste le notevoli dimensioni corporee e la bassa frequenza di animali spiaggiati in buone condizioni di conservazione. Oltre a questo, il cranio del capodoglio ha subito una notevole trasformazione per ospitare l'organo dello spermaceti e la cavità cranica, essendo racchiusa da spessi strati ossei, diventa difficile da raggiungere nel corso di una dissezione sul campo.

\footnotetext{
${ }^{1}$ Department of Comparative Biomedicine and Food Science of the University of Padova, Viale dell'Università 16,

35020 Legnaro (PD), Italia

${ }^{2}$ Natuurhistorische collectie, Universiteitsmuseum Utrecht, Lange Nieuwstraat 106, 3512 PN, Utrecht, Nederland

${ }^{3}$ Sezione di Zoologia dei Vertebrati, Museo Civico di Storia Naturale di Milano, Corso Venezia 55, 2012 Milano. Italia

${ }^{4}$ Scientific Illustrator, Piazzale Piola 5, 20131 Milano, Italia

* Corresponding author: michela.podesta@comune.milano.it; michela_podesta@hotmail.com
}

(C) 2014 Michele Povinelli, Mattia Panin, Sandro Mazzariol, Maristella Giurisato, Cristina Ballarin, Giulia Roncon,

Michela Podestà, Massimo Demma, Bruno Cozzi

Received: $10^{\text {th }}$ November 2014

Accepted for publication: $20^{\text {th }}$ November 2014
Recentemente abbiamo avuto l'opportunità di estrarre il cervello da due capodogli spiaggiati ed in buono stato di conservazione. Nel presente articolo si descrivono le principali caratteristiche macroscopiche (inclusi il peso dell'organo e il Quoziente di Encefalizzazione), viene riportata un'analisi della letteratura pertinente e viene descritto un possibile nuovo metodo per l'estrazione e la conservazione di questo organo.

Parole chiave: encefalo capodoglio; Quoziente di Encefalizzazione; mammiferi marini; spiaggiamenti; peso encefalo

\section{INTRODUCTION}

References on the morphology, size, and structure of the brain of the sperm whale (Physeter macrocephalus, Linnaeus 1758) are limited, possibly due to the several problems related to describing the internal organs of large marine animals and to the complications associated to tissue sampling under often critical field conditions. The sampling of the brain is very challenging for the imposing dimensions of the sperm whale head, for the size of the brain, and for its position at the lowest and caudalmost extremity of the skull. In fact removal of the organ requires skilled operators, adequate safety measures and suitable heavy-duty equipment. Kojima (1951) in his seminal paper on the subject described the sampling phases, and the difficulties of the whole process, performed on board a Japanese whaling vessel, as follows: "The brain was taken out from the huge cranium, using such tools as chisel, gimlet or hatchet, after the bone was cut by a bone-saw into a block properly shaped for extraction of the brain, or after sagittal sectioning of the cranium into halves, two separated parts of the brain gathered".

The data available in the literature and summarized in Tab. 1 indicate that the encephalon of the sperm whale drew some attention especially in the late '50s and early '70s. However only a few of the published articles report original values for the weight of the brain, while other investigations based their conclusions on earlier records. The interest in the central nervous system of this large toothed whale dwindled in the last decades and even relatively recent studies rely on the work of the early Authors. We also emphasize that most data are relative to the brain of male individuals, and the documentation relative to females is limited to two sexually mature specimens sampled by Berzin (1971). 
Tab. 1 - Data available in the literature on the brain of the sperm whale Physeter macrocephalus.

\begin{tabular}{|c|c|c|c|c|c|c|}
\hline Reference & $\begin{array}{c}\text { \# of } \\
\text { animals }\end{array}$ & $\begin{array}{l}\text { Absolute } \\
\text { brain weight (g) } \\
\text { and sex }\end{array}$ & $\begin{array}{c}\text { Average } \\
\text { brain weight } \\
\text { (g) }\end{array}$ & $\begin{array}{c}\text { Body } \\
\text { weight } \\
\text { (kg) }\end{array}$ & $\begin{array}{c}\text { Original } \\
\text { data }\end{array}$ & Notes \\
\hline Ries \& Langworthy (1937) & 1 & 7980 & & & Yes & formalin fixed \\
\hline Quiring (1943) & 1 & 8338 え & & 39000 & Yes & \\
\hline Kojima (1951) & 16 & 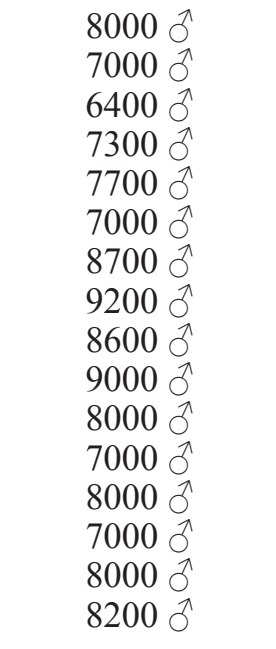 & 7819 ठ & & Yes & $\begin{array}{l}\text { brain weight } \\
\text { approx. due to } \\
\text { sampling on a } \\
\text { whaling vessel }\end{array}$ \\
\hline Sleptsov (1952) & 1 & 6500 ठ & & & Yes & $\begin{array}{l}\text { cited by Berzin } \\
\text { (1971) }\end{array}$ \\
\hline Jacobs \& Jensen (1964) & 1 & 9200 ठ & & 36700 & $?$ & formalin fixed \\
\hline Mangold-Wirz (1966) & 1 & 5428 ठ & & 17000 & & \\
\hline Pilleri et al. (1968) & 14 & & 7826 Љ & & No & 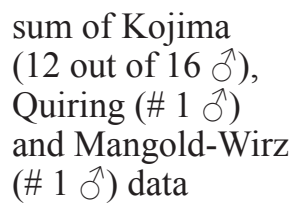 \\
\hline $\begin{array}{l}\text { Yablokov cited by Berzin } \\
\text { (1971) }\end{array}$ & 2 & $\begin{array}{l}8300 \hat{0} \\
6700 \hat{~}{ }^{\lambda}\end{array}$ & & & Yes & $\begin{array}{l}\text { cited by Berzin } \\
\text { (1971) without any } \\
\text { specific indication } \\
\text { of date }\end{array}$ \\
\hline Berzin (1971) & 25 & 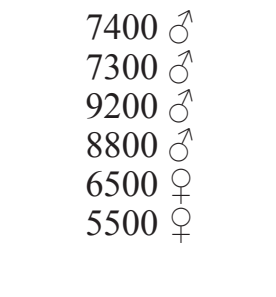 & $\begin{array}{l}7900 \stackrel{1}{0} \\
6000 \text { 古 }\end{array}$ & & $\begin{array}{c}\text { No } \\
(\# 190) \\
\text { Yes } \\
(\# 40 \\
\text { and } 29 \text { ) }\end{array}$ & 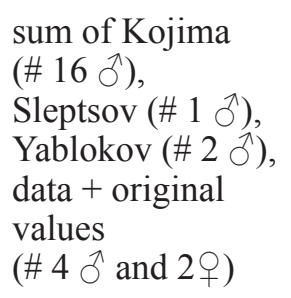 \\
\hline $\begin{array}{l}\text { Ridgway \& Brownson } \\
\text { (1984) }\end{array}$ & 16 & & 7818 ふ & 37094 & No & $\begin{array}{l}\text { original data by } \\
\text { Kojima (1951) }\end{array}$ \\
\hline Marino (2002) & & & 8028 & 35833 & $?$ & $\begin{array}{l}\text { no reference is } \\
\text { given }\end{array}$ \\
\hline
\end{tabular}


The sperm whale is a common inhabitant of Mediterranean waters (Cagnolaro et al., 2014), and strandings of single individuals of this species are relatively frequent along the Italian shores. The Italian stranding network, established with the help of the Italian Ministry of the Environment and the Italian Ministry of Health (Veterinary Division) includes a mobile Emergency Unit ${ }^{1}$, a tissue bank for long term storage and preservation of sampled tissues $^{2}$, and immediate veterinary medical intervention ${ }^{3}$. The three compartments called upon strandings of large marine mammals possess the instruments required to perform on-site necropsy on large marine animals, and are also equipped and trained to contain potential biological hazards and avoid personal risks for the operators. In December 2009 seven young male P. macrocephalus stranded along the sandy coast close to Peschici (FG) in the Southern Adriatic Sea. A complete necropsy, on three out of seven individuals, was performed on site by the joint team (for a detailed report of the event see Mazzariol et al., 2011). Removal of the brains was attempted but resulted impossible to accomplish, because of the deep position of the organ, the absence of proper tools, and ultimately because of adverse field conditions. However, in September 2014 a school of seven sperm whales stranded close to Vasto $(\mathrm{CH})$, approx. $150 \mathrm{~km}$ North of the former stranding site. Rescue by local fishing boats and redirection to open waters was attempted with success with four components of the school, but three whales died on the sandy shore. Necropsies were performed on the stranded animals, and the extraction of the brain was attempted with a novel approach based on former experience and use of proper sawing tools.

In the present article we describe the relatively simple and direct method employed to remove the brains of the stranded animals, and report a short preliminary description of their key macroscopic features including the weight and Encephalization Quotient (EQ).

\section{MATERIALS AND METHODS}

\section{Animals}

Brains were sampled from three mature female sperm whales P. macrocephalus, stranded in September 2014 near Vasto ${ }^{4}$. One animal stranded dead and the remaining two were in poor health conditions and died soon afterwards. The carcasses were then dragged to firmer sandy grounds with two excavators and the necropsy started approx. 20 hours after death. The basic biological data of the animals are reported in Tab. 2. Detailed post-mortem analyses are still in progress and a thorough report on the possible causes of death will be published later.

\section{Extraction tools and methodology}

To extract the brain we employed a motorized MS 460 (Stihl) professional chainsaw, with a blade length of 50 $\mathrm{cm}$. Other instruments employed included standard tools for the necropsy of large domestic herbivores.

Since we propose here a new method to remove the brain of these large whales, the technique is described in the Results section.

\section{Tissue fixation and weighing methods}

One of the three brains, belonging to the animal stranded dead (ID \# 337), was in advanced decomposition and therefore discarded. The two remaining brains were immersed in buffered $10 \%$ formaldehyde and sealed in separate containers. The mass of the brains was such that successful penetration of the fixative would have been too slow to obtain an acceptable preservation of the tissues. Therefore, each brain was separated into two halves and, upon arrival at the facility in Padova, moved to larger containers (approx. 751 each) filled with fresh fixative, so that a larger volume of formaldehyde could apply a higher hydrostatic pressure and thus obtain a more efficient penetration. The containers were stored at $4{ }^{\circ} \mathrm{C}$. After one month the brains were photographed. Weights of the wet half-brains were determined using a precision electronic scale. Possible variations due to formalin fixation were taken into account, following an established protocol (Cozzi et al., 2014).

The total body weight was estimated using the formula $\left(\mathrm{W}=0.0218 \mathrm{~L}^{2.74}\right.$, where $\mathrm{W}$ is body weight and $\mathrm{L}$ is total body length) by Lockyer (1976), which takes into account an approx. $10 \%$ of loss of weight due to leakage of body fluids during dissection.

\section{Encephalization Quotient}

We calculated the EQ for the two animals using the classical formula $\left(\mathrm{EQ}=\mathrm{E}_{i} / 0.12 \mathrm{P}^{2 / 3}\right.$, where $\mathrm{E}_{\mathrm{i}}$ is brain weight and $\mathrm{P}$ is body weight) of Jerison (1973).

\section{RESULTS}

At the present time a definite cause of death has not been yet established for the stranded whales. Preliminary data gathered on site, based on macroscopic examination of the animal bodies showed no signs of trauma nor of cerebral damage. Further analyses are in progress and will be published later.

Tab. 2 - ID number and size of sampled animals. *pregnant female

\begin{tabular}{|l|c|c|c|}
\hline $\begin{array}{l}\text { Animal number } \\
\text { (MMMTB identity) }\end{array}$ & $\begin{array}{c}\text { Total length } \\
\text { (cm) }\end{array}$ & $\begin{array}{c}\text { Body height near the eye } \\
\text { (cm) }\end{array}$ & $\begin{array}{c}\text { Estimated weight } \\
\text { (kg) }\end{array}$ \\
\hline ID 335 (SW1)* & 895 & 168 & 8840 \\
\hline ID 337 (SW2) & 838 & 155 & 7382 \\
\hline ID 338 (SW3) & 733 & 117 & 5115 \\
\hline
\end{tabular}




\section{Extraction of the brains}

After rapid removal of the skin, blubber, and neck muscle layers down to the dorsal edge of the spine, a winch was secured to the tip of the jaws of the sperm whales and atlanto-occipital dislocation was obtained applying increasing tension on the cable. Once the head was separated from the neck, soft tissues were removed from the occipital bone to achieve a clear view of the back of the skull. Using the chainsaw in a circular way, a cut was then made around the base of the occipital condyles (Fig. 1), and the latters were forcefully detached with a lever. Removal of the condyles revealed the temporo-occipital lobes of the brain located almost vertically above the large cerebellum. The inner surface of the condyles is concave to adapt for the huge neocerebellar lobes, and therefore extra care was taken not to damage their lateral margins during incision of the bone.

The brain was covered by the light-gray dura mater, that lacerated easily because of the torsion forces applied by the saw on the adjacent bone frame of the condyles. The brains were separated from the dura mater that kept the lower surface of the brainstem and cranial nerves attached to the basi-occipital bone using large forceps and scissors, and then manually removed from the osseous cavity. The whole procedure lasted approx. one hour.
Weight of the brain and notes on its surface anatomy

The general shape of the brain of the sperm whale is characterized by an evident lateral extension of the temporal lobes. The telencephalon is placed almost vertical over the cerebellum in a quite unique position. The rotation along the transverse inter-insular axis is very pronounced, placing the Sylvian cleft in an almost vertical position (Fig. 2). The outer surface shows an intense pattern of gyri, separated by moderately deep sulci in which relatively large pial vessels are well evident.

The weights of the brains are reported in Tab. 3 .

In Tab. 3 we reported also a possible correction of the brain weight due to immersion in formaldehyde, according to Cozzi et al. (2014). However the brain has been immersed in the fixation fluid only for four weeks, and in such a short period the increase in weight is minimal, if present at all.

\section{Encephalization Quotient}

The EQs of the two sperm whales, obtained applying Jerison's formula (Jerison, 1973) are reported in Tab. 3. The same values are reported in Tab. 4 for comparison with other representative mammals, including some cetaceans. Fig. 3 represents a logarithmic plot of body weight against brain weight for the same species listed in Tab. 4, with the corresponding references.
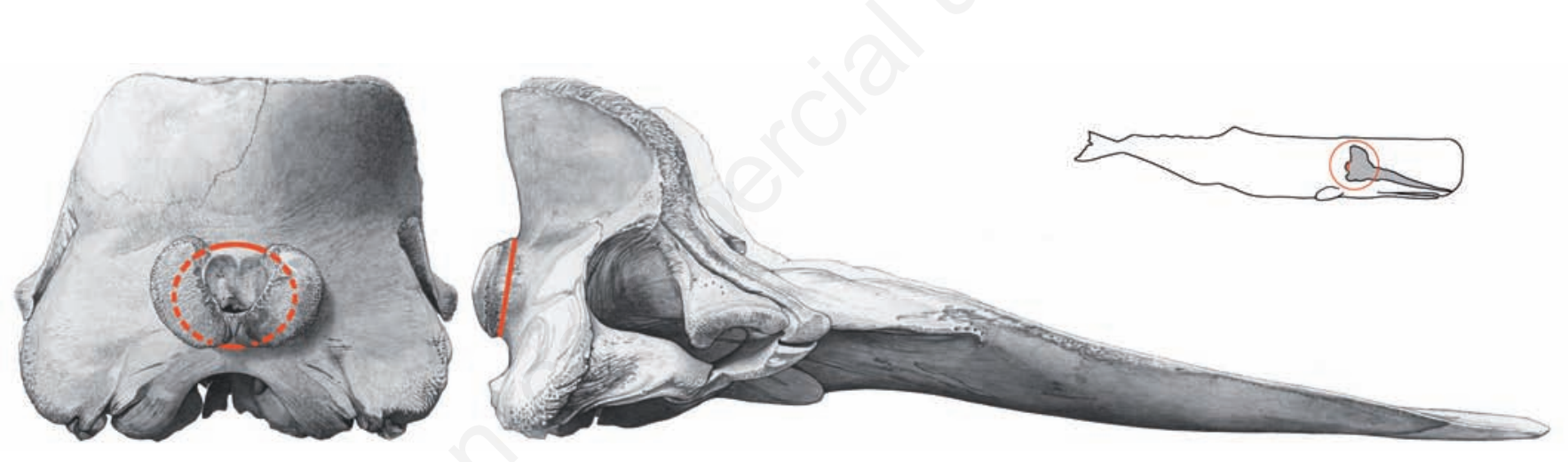

Fig. 1 - Drawings of the skull of Physeter macrocephalus, showing a caudal (left) and a lateral (center) view. Red dashed lines indicate the plane of section described in the article. The relative position of the condyles to the profile of the sperm whale is represented in the schematic drawing on the right. (Drawing by M. Demma).

Tab. 3 - Brain weights and Encephalization Quotients of sampled animals.

\begin{tabular}{|l|c|c|c|c|c|}
\hline $\begin{array}{l}\text { Specimen ID } \\
\text { (MMMTB) }\end{array}$ & $\begin{array}{c}\text { Weight of the } \\
\text { half brain (g) }\end{array}$ & $\begin{array}{c}\text { Estimated weight of the } \\
\text { whole brain (g) }\end{array}$ & eW + FI (g) & EQ & EQ + FI \\
\hline ID 335 & 3350 & 6700 & 6070 & 1.31 & 1.18 \\
\hline ID 338 & 3600 & 7200 & 6521 & 2.02 & 1.27 \\
\hline
\end{tabular}

eW + FI: estimated weight of the whole brain after correction for formalin immersion.

EQ: Encephalization Quotient.

EQ + FI: Encephalization Quotient after correction for formalin immersion. 


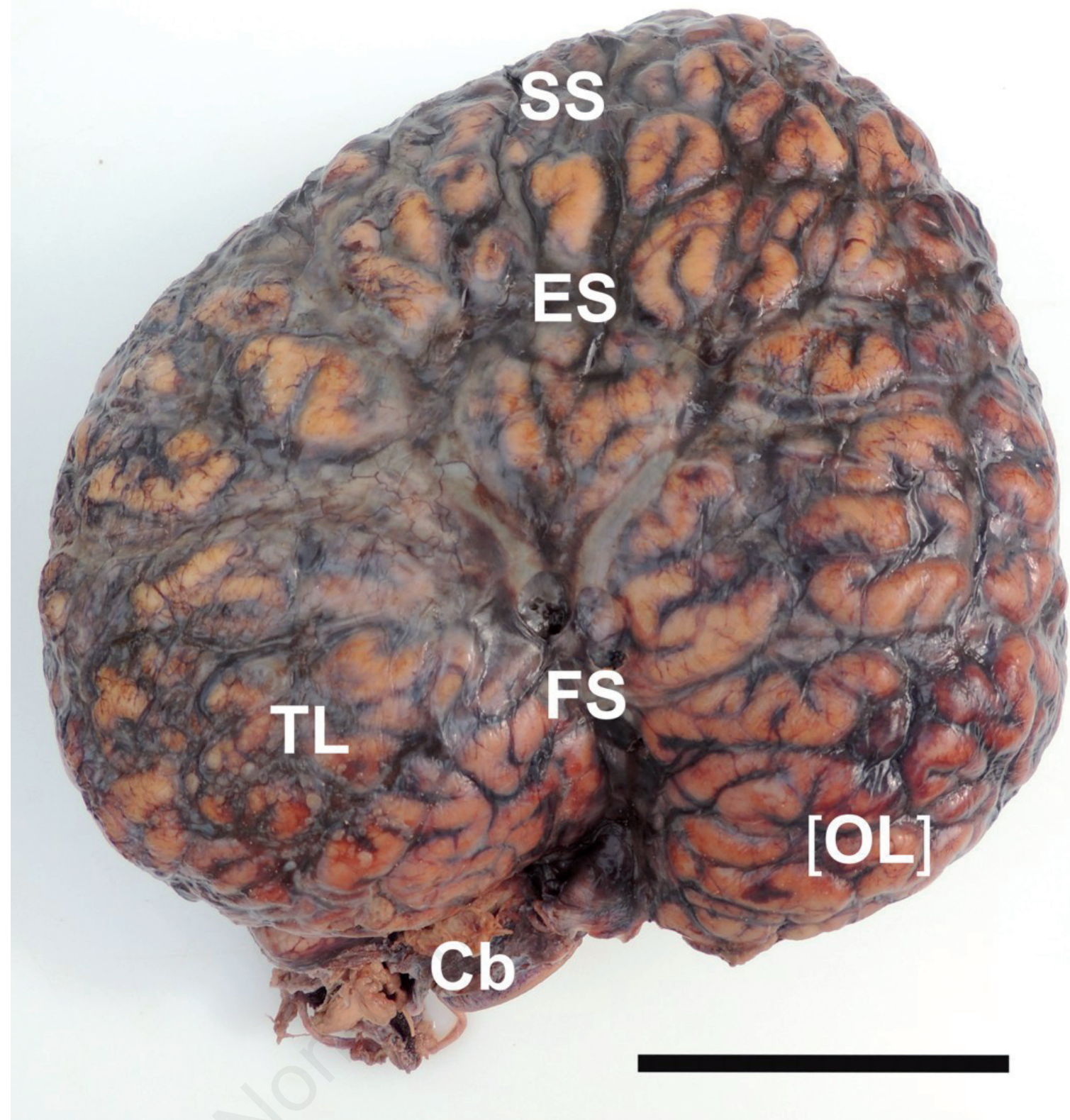

Fig. 2 - Photograph of the right side of the brain of sperm whale ID 335. FS, Sylvian cleft; Cb, cerebellum; TL, temporal lobe; ES, ectosylvian sulcus; SS, suprasylvian sulcus; $[\mathrm{OL}]$, presumed position of the orbital lobe. Black bar $=10 \mathrm{~cm}$

\section{DISCUSSION}

Data on the weight of the sperm whale brain are relatively scarce, as reported in Tab. 1. In fact the two main sources of information are the papers by Kojima (1951) and Berzin (1971), both describing biological materials obtained during whaling campaigns. Handling of the large body of an adult sperm whale may require adequate machineries, and a number of safety precautions that are not easy to apply directly on stranding sites.

A key factor was the previous experience gained during a former mass stranding occasion in 2009 (Mazzariol et al., 2011) when removal of the brain was attempted with a traditional approach and an horizontal cut, but failed because of the thickness of the brain case and the very deep position of the brain. The former unproductive experience suggested an alternative approach to the brain case. The vertical approach, described in the present article, included a circular cut applied perpendicularly to the base of the occipital condyles after detachment of the head from the thorax, and allowed us to collect two large brains of this species. With the technique that we propose here, removal of the brain may be attempted whenever the necessary equipment is available, safety conditions warrant it, and the operators possess the required skills.

The very large brain of the sperm whale has external features that resemble those of the African bush elephant (Loxodonta africana (Blumenbach, 1797)) (for recent literature and debate on the elephant brain 


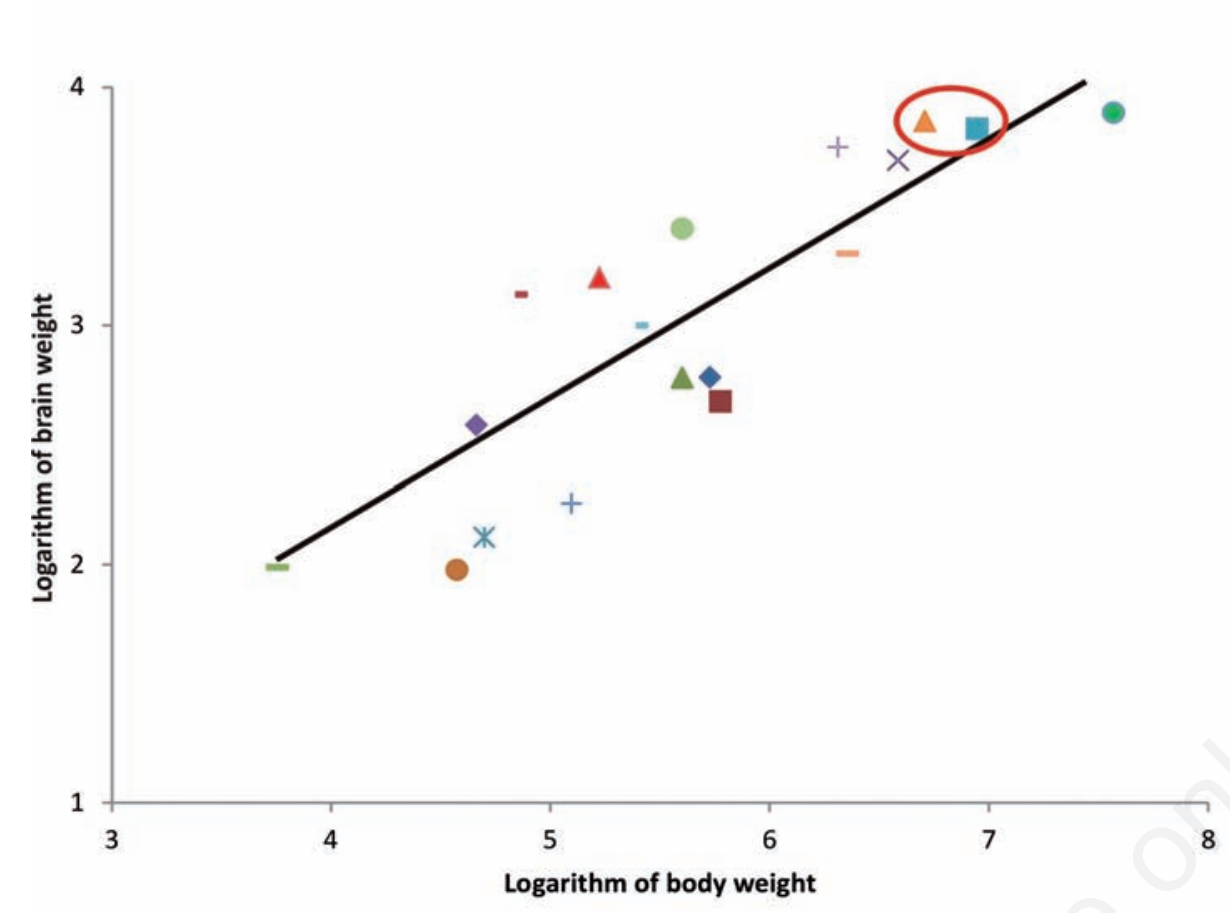

- Equus caballus

- Bos taurus

- Camelus bactrianus

$\times$ Loxodonta africana

* Ovis aries

- Caprah. aegagrus

+ Sus scrofa

- Homo sapiens

- Hylobates sp.

- Pan troglodytes

ID 335

$\triangle$ ID 338

- Physeter macrocephalus

A Tursiops truncatus

Grampus griseus

+ Orcinus orca

- Kogia breviceps

- Ziphius cavirostris

Fig. 3 - Logarithmic plot of the brain and body weight of several mammals. The solid black line represents the expected values for the equation $\mathrm{EQ}=\mathrm{E}_{\mathrm{i}} / 0.12 \mathrm{P}^{2 / 3}$ following Jerison (1973). The predictable brain weight for a given body weight should ideally fall along the line. Values above the line represent a brain mass higher than expected for a given body weight. The sources of the data are listed in Table 4. ID 335 and ID 338 represent the values of our two sperm whales (encircled by the red line) to distinguish them from published value for the same species.

Tab. 4 - Brain weight (g), body weight $(\mathrm{kg})$ and EQ of selected mammalian species.

\begin{tabular}{|l|c|c|c|l|}
\hline Species & Brain weight (g) & Body weight (kg) & EQ & Reference \\
\hline Loxodonta africana & 4927 & 3850 & 1.671453 & Shoshani et al. (2006) \\
\hline Hylobates sp. & 97.5 & 5.7 & 2.546284 & Shultz \& Dunbar (2010) \\
\hline Pan troglodytes & 382.1 & 46 & 2.480222 & Shultz \& Dunbar (2010) \\
\hline Homo sapiens & 1350 & 70 & 6.623494 & Miller \& Cosellis (1977) \\
\hline Equus caballus & 605.6 & 535.2 & 0.765586 & Cozzi et al. (2014) \\
\hline Sus scrofa & 180.4 & 124.64 & 0.602491 & Shultz \& Dunbar (2010) \\
\hline Camelus bactrianus & 603 & 400 & 0.925613 & Chen et al. (2007) \\
\hline Bos taurus & 480.6 & 597 & 0.564876 & own data \\
\hline Capra h. aegagrus & 95 & 37.5 & 0.706624 & Bossi et al. (1909) \\
\hline Ovis aries & 130 & 50 & 0.798207 & Nickel et al. (1988) \\
\hline Tursiops truncatus & 1587.5 & 167.4 & 4.355408 & Ridgway (1986) \\
\hline Grampus griseus & 2551 & 400 & 3.915818 & Ridgway (1986) \\
\hline Orcinus orca & 5617.7 & 2049.2 & 2.901713 & Ridgway (1986) \\
\hline Ziphius cavirostris & 2004 & 2273 & 0.966014 & Ridgway (1986) \\
\hline Kogia breviceps & 999 & 248 & 2.109032 & Ridgway (1986) \\
\hline Physeter macrocephalus & 7818.8 & 37093.8 & 0.585812 & Ridgway (1986) \\
\hline P.m.\# ID 335 & 6700 & 8840 & 1.305946 & this study \\
\hline P.m.\# ID 338 & 7200 & 5115 & 2.021099 & this study \\
\hline
\end{tabular}


see Herculano-Houzel et al., 2014; for analysis of older gray literature see Cozzi et al., 2001) for the lateral development of the temporal lobes and the general outline of the telencephalon, but the reciprocal position of the telencephalon and cerebellum of Physeter macrocephalus is quite unique. Comparisons with the brain of a fin whale (Balaenoptera physalus (Linnaeus, 1758)) of corresponding length, also maintained at the MMMTB (data not shown), indicate that the brain of P. macrocephalus is indeed heavier and larger, a fact often reported in the literature (for a general review see Marino, 2002). The weights that we report here agree with the values described in the series of Kojima (1951) and Berzin (1971). We emphasize here that the large majority of weight values in the literature are referred to male sperm whales, and data from adult females are limited to two specimens included in the Berzin (1971) series. This is probably due to the fact that in this species mature males are bigger than females, and therefore potentially more commonly harvested by whaling fleets. An alternate explanation is that, given the choice to perform the complex operation of brain extraction on a number of specimens limited by practical circumstances on-board, the operator prefers the largest specimens that may yield the highest brain weights. Moreover, the allometric equations available in the literature to calculate body weight from total length are based on specimens longer than $10 \mathrm{~m}$ (Rice, 1989), and therefore probably unfit for a proper estimate in case of smaller female individuals as is our case. Females attain a shorter maximum length than males and undergo a different pattern of body growth (Rice, 1989), so we think that a different equation should be obtained in future studies.

The EQs of two sperm whales described here is surprisingly high, considering what reported in terrestrial mammals (Fig. 4) (for a recent discussion on the application of the formula to the brain of large species and EQ data see Cozzi et al., 2014; for a thorough discussion of mammalian brains larger than $700 \mathrm{~g}$ see Manger et al., 2013). Previous reports identified lower EQ values in large whales, including sperm whales. However we stress here that male Physeter macrocephalus have slightly larger brains, but much heavier bodies than females. Therefore, since most brain weights reported in the literature are referred to male specimens, the resulting EQs are much lower. A thorough discussion of the importance of the remarkable EQs of our two female sperm whales is outside the scope of this preliminary note. Here we note that EQ values equal or above 1 identify species whose encephalon is considerably well developed and presumably reflect an overall evolutionary advanced environmental or social adaptation. The data that we obtained for our two sperm whales are comparable or above to what described for the African bush elephant, and on the same level of several primates (except man) (Cozzi et al., 2014).

Our observations on the external morphology of the brain confirm what reported in the detailed and thorough paper by Kojima (1951). However, to the best of our knowledge, Fig. 2 represents the first published photograph of an adult sperm whale brain. We are aware that modern printing techniques and the currently reduced costs of on-line publication may facilitate the inclusion of photographs into scientific articles, a condition that did not apply to all the publications of the second half of the XX century. Nevertheless our experience suggests also that the fixation procedures required by such a large brain may severely hamper the final outcome of the whole preservation process and suggest the use of drawings opposed to photographs. The mass of the tissue is such that there are not many readily available containers that may accommodate it, including also an adequate volume of fixative that guarantees a relatively fast penetration into the tissues. Furthermore, the whole brain is so heavy that tends to collapse upon itself and to damage or at least distort the parts that lay underneath. To improve the fixation process, we decided to separate the brain into two halves, thus reducing the whole quantity of aldehydes inside each container, and curtailing potential structural damages since the callosal side may lay flat on the bottom of the container. This allowed us to obtain a series of acceptable images of the brain.

The possibility to achieve a sufficient condition of preservation is a key feature for the scientific exploitation of this precious material. Up to now the only study dedicated to the structure of the sperm whale brain (Oelschläger \& Kemp, 1998) concerns fetal specimens, whose brain is of inferior volume. We are presently evaluating the quality of our material for possible future studies.

\section{Acknowledgments}

The Authors wish to thank Dr. Giuseppe Palmisano and Mr. Emanuele Zanetti, for their precious contribution to the preservation of the brain.

\section{NOTES}

${ }^{1}$ The Cetacean Emergency Rescue Team (CERT), based at the University of Padova.

2 The Mediterranean marine mammal tissue bank (MMMTB, www.marinemammals.eu), also based at the University of Padova.

3 By the regionally located Istituti Zooprofilattici Sperimentali (State Institutes for Animal Health, IZS).

4 Four more whales, part of the same pod, were successfully towed back to the high seas. Another sperm whale was found dead afloat ten days later approx. 200 $\mathrm{km}$ South of the stranding site in Vasto. The conditions of the carcass made it impossible to ascertain whether this latter individual was a component of the formerly stranded pod.

\section{REFERENCES}

Berzin A. A., 1971 - Central nervous system and sense organs. In: Kashalot (The sperm whale). Yablokov A.V. (ed.). Israel Program for Scientific Translations, Jerusalem: 142-151.

Bossi V., Caradona G. B., Spampani G., Varaldi L. \& Zimmerl U., 1909 - Sistema nervoso ed estesiologia. In: Trattato di anatomia veterinaria, Vol. III. Zimmerl U. \& Bossi V. (eds). Vallardi, Milano. 
Cagnolaro L., Cozzi B., Notarbartolo di Sciara G. \& Podestà M., 2014 - Fauna d'Italia, XLIX, Mammalia IV, Cetacea. Calderini, Bologna.

Chen C. J., Juan G. C., Tian B. Z. \& Lin W. J., 2007 Morphological comparisons of the brain of the Bactrian camel (Camelus bactrianus) between a near term foetus and the adult. Journal Of Camel Practice And Research 14: 139-142.

Cozzi B., Spagnoli S. \& Bruno L., 2001 - An overview of the central nervous system of the elephant through a critical appraisal of the literature published in the XIX and XX centuries. Brain Research Bulletin., 54: 21927.

Cozzi B., Povinelli M., Ballarin C. \& Granato A., 2014 The brain of the horse: weight and cephalization quotients. Brain Behavior and Evolution, 83: 9-16.

Herculano-Houzel S., Avelino-de-Souza K., Neves K., Porfírio J., Messeder D., Mattos Feijó L., Maldonado J. \& Manger P. R., 2014 - The elephant brain in numbers. Frontiers in Neuroanatomy, 8:46. doi: 10.3389/ fnana.2014.00046.

Jacobs M. S. \& Jensen A. V., 1964 - Gross aspects of the brain and a fiber analysis of cranial nerves in the great whale. Journal of Comparative Neurology, 123: $55-72$.

Jerison H. J., 1973 - Evolution of the brain and intelligence. Academic Press, New York.

Kojima T., 1951 - On the brain of the sperm whale (Physeter catodon L.). Scientific Reports of the Whales Research Institute, 6: 49-72.

Lockyer C., 1976 - Body weights of some species of large whales. Journal du Conseil Permanent International pour l'Exploration de la Mer, 36: 259-273.

Manger P. R., Spocter M. A. \& Patzke N., 2013 - The evolutions of large brain size in mammals: the 'over700-gram club quartet. Brain Behavior and Evolution, 82: 68-78.

Mangold-Wirz, K. 1966 - Cerebralisation und ontogenesemodus bei eutherien. Acta Anatomica, 63: 449508.

Marino L., 2002 - Brain Size Evolution. In: Encyclopedia of marine mammals. Perrin W. F., Wursig B. \& Thewissen J. G. M. (eds.). Academic Press, San Diego: 158-162.

Mazzariol S., Di Guardo G., Petrella A., Marsili L., Fossi C. M., Leonzio C., Zizzo N., Vizzini S., Gaspari S., Pavan G., Podestà M., Garibaldi F., Ferrante M., Copat C., Traversa D., Marcer F., Airoldi S., Frantzis A., Quirós Yde B., Cozzi B. \& Fernández A., 2011 Sometimes sperm whales (Physeter macrocephalus) cannot find their way back to the high seas: a multidisciplinary study on a mass stranding. PLOS ONE 6: 1-17. doi:10.1371/journal.pone.0019417

Miller A. K. \& Cosellis Y. A., 1977 - Evidence for a secular increase in human brain weight during the past century. Annals of Human Biology, 4: 253-257.

Nickel R., Schummer A. \& Seiferle E., 1988 - Sistema Nervoso e Organi di Senso. In: Trattato di anatomia degli animali domestici, Vol. IV. Gobetto A. \& Godina G. (eds). Casa Editrice Ambrosiana, Milano.
Oelschläger H. H. \& Kemp B., 1998 - Ontogenesis of the sperm whale brain. Journal of Comparative Neurology, 399: 210-228.

Pilleri G., Kraus C. \& Gihr M., 1968 - The structure of the Cerebral Cortex of the Gange Dolphin Susu (Platanista). Zeitschrift für Mikroskopisch-anatomische Forschung (Leipzig), 79: 373-388.

Quiring D. P., 1943 - Weight data on five whales. Journal of Mammalogy, 24: 39-44.

Rice D. W., 1989 - Sperm whale Physeter macrocephalus Linnaeus, 1758. In: Handbook of marine mammals. Volume 4. Ridgway S. H. \& Harrison R. (eds.). Academic Press, London: 177-233.

Ridgway S. H., 1986 - Dolphin brain size. In: Research on dolphins. Bryden M. M. \& Harrison R. (eds.). Clarendon Press, London: 59-70.

Ridgway S. H. \& Brownson R. H., 1984 - Relative brain sizes and cortical surface areas in odontocetes. Acta Zoologica Fennica, 172: 149-152.

Ries F. A. \& Langworthy O. R., 1937 - A study of the surface structure of the brain of the whale (Balaenoptera physalus and Physeter catodon). Journal of Comparative Neurology, 68: 1-47.

Shoshani J., Kupsky W. J. \& Marchant G. H., 2006 Elephant brain. Part I: gross morphology, functions, comparative anatomy, and evolution. Brain Research Bulletin, 70: 124-157.

Shultz S. \& Dunbar R., 2010 - Encephalization is not a universal macroevolutionary phenomenon in mammals but is associated with sociality. Proceedings of the $\mathrm{Na}$ tional Academy of Sciences, 107: 21582-21586.

Sleptsov M. M., 1952 - Kitoobraznye dal'nevostochnykh morei (Whales of the Far East). Izvestiya TINRO 32. 